\title{
Economic and Environmental Impacts of Mass Tourism on Regional Tourism Destinations in Indonesia*
}

\author{
Jung Wan Lee ${ }^{1}$, Ahmad Mujafar Syah ${ }^{2}$
}

Received: March 30, 2018 Revised: July 14, 2018 Accepted: July 30, 2018

\begin{abstract}
The study examines economic and environmental impacts of mass tourism on regional tourism destinations, particularly the establishment of "Ten New Bali", in Indonesia. The sample is restricted to the period of time in which annual data is available and comparable among variables from 1980 to 2015 (36 observations). All of the time series data was collected and retrieved from the World Development Indicator database published by the World Bank. This study applies cointegrating regression analysis using the fully modified OLS, canonical cointegrating regression, and dynamic OLS. The results of the study suggest that 1) there is a long-run equilibrium relationship between tourism receipts, environmental degradation and economic growth in Indonesia, 2) tourism growth and agriculture land growth are positively related to an increase of total output in the short-run in Indonesia, and 3) arable land is significant at the 0.01 level, but forest rents and CO2 from transport are not significant in the short-run in Indonesia. The results confirm that arable land is negatively related to an increase of total output in Indonesia. That is, when tourism growth in the economy is getting realized it shows that the environmental degradation increases greatly in inverse in the model, eventually negative impacts to the environment.
\end{abstract}

Keywords: Environmental Impact, Tourism Destinations, Regional Tourism, Ten New Bali, Indonesia.

JEL Classification Codes: F63, F64, O13, O44, O53.

\section{Introduction}

Indonesia, a rich archipelago in Southeast Asia is urging more aggressive responses toward tourism establishment

* The paper with the title ["Economic and Environmental Impacts of Mass Tourism on Regional Tourism Destinations: A Case Study of Ten New 'Bali' in Indonesia"] was presented initially at 2017 International Conference on Business and Economics (ICBE2017) and the 12th International Conference of KODISA that was held in Ho Chi Minh City, Vietnam, July 6-8, 2017. The paper has been recognized as one of Distinguished Paper Awards at ICBE2017 conference. This paper is a substantially revised and expanded version of the paper presented at ICBE2017 conference. The authors have taken into account all the comments of Editors, Session Chairs and Reviewers in the revised manuscript. The authors greatly appreciate Editors, Session Chairs and Reviewers for their valuable comments, interest in and support of this research.

1 First Author and Corresponding Author. Assistant Professor, Administrative Sciences Department, Metropolitan College, Boston University [Postal Address: 808 Commonwealth Avenue, Boston, MA 02215, USA] Email: jwlee119@bu.edu

2 Graduate Student, Administrative Sciences Department, Metropolitan College, Boston University, Boston, USA Email: syah@bu.edu benefiting respective destination from the profits contributed by progressive imported goods and service as well as job opportunities; to say the least, in spite of so many leakages both economically and politically causing collateral damages and unfairness throughout top-down stakeholders' layers; the locals. There are social and environmental impacts from massive tourism profit occupation by dominant market shares creating simultaneous economic absorbance inequality. In contrast, aside from the factual issues in locals economy and social growth, the dynamic results of this emerging industry are creating some sentiment movements from national government toward harder efforts in gearing the partnerships and business investments. Moreover, the stakeholder's assessments which likewise, should have been formed by destination community engagements seem stagnant down the road in its theoretical involvement owing to the huge discrepancies between the investors with their real cash and agenda and working class indigenous locals.

The continuous efforts for Indonesia's tourism establishment, both infrastructure and intangible development even during the hard crisis of economy, social and environmental inequalities are visible because, like majority of Southeast Asian Counties, Indonesia felt the beneficial deployment of tourism during the period of 80 's to 
90's. That supplied a strong stimulus acknowledging the country's capability to compete within the market. Having been able to maintain the economic growth and receive the demands of "mass tourism", the island of Bali, for instance, is generating a large tourism revenue for Indonesia and receiving the largest international tourist arrivals, reported 1.5 million foreign tourists for between January and May 2015 and expected to receive at least 4 million visitors for the whole year of 2015 (Indonesia-Investments, 2016).

A famous destination for international tourism, Indonesia has a growing number of foreign tourist arrivals, both for leisure and business. With a long average stay and high daily spending, tourists are important for many businesses in the country. According to tourism reports (IndonesiaInvestments, 2016; World Travel \& Tourism Council, 2017), Indonesia has received 9.435 million tourists in 2014 coming primarily from East Asia and the Pacific and Europe. They entered the country through airports (about 74\%) and from the sea (about 25\%). Tourists spent a total of 11.567 billion US\$ in the country in 2014, with 1.306 billion US\$ on passenger transport and 10.261 billion US\$ on their travel. Their habits show an average length of stay of 7.66 days and an average daily expenditure of 154.40 US\$. Indonesian Tourism Minister Arif Yahya said that the government is currently busy promoting ten tourist destinations to tourists, see Table 1.

Table 1. 10 Priority Tourist Destinations of the Indonesian Government

\begin{tabular}{|c|c|c|}
\hline Destination & $\begin{array}{c}\text { Tourists } \\
\mathbf{2 0 1 3}\end{array}$ & $\begin{array}{c}\text { Tourist Target } \\
\mathbf{2 0 1 9}\end{array}$ \\
\hline Borobudur (Central Java) & 227,337 & $2,000,000$ \\
\hline Mandalika (Lombok) & 125,307 & $1,000,000$ \\
\hline Labuan Bajo (Flores) & 54,147 & 500,000 \\
\hline $\begin{array}{c}\text { Bromo-Tengger-Semeru } \\
\text { (East Java) }\end{array}$ & 33,387 & $1,000,000$ \\
\hline $\begin{array}{c}\text { Thousands Islands } \\
\text { (off the coast of Jakarta) }\end{array}$ & 16,384 & 500,000 \\
\hline Toba Lake (North Sumatra) & 10,680 & $1,000,000$ \\
\hline Wakatobi (Sulawesi) & 3,315 & 500,000 \\
\hline Tanjung Lesu (Banten) & 1,739 & $1,000,000$ \\
\hline Morotai (Halmahera, Maluku) & 500 & 500,000 \\
\hline $\begin{array}{c}\text { Tanjung Kelayang } \\
\text { (Bangka Belitung) }\end{array}$ & 451 & 500,000 \\
\hline
\end{tabular}

Source: Indonesia-Investments (2016)

In response to the increasing demands of tourism destinations, the Ministry of Tourism and Creative Economy under the mandate from the Indonesian President in 2016 has initiated a mega project called "Ten New Bali" (Tunggono, 2016). The areas of destination planned to be developed are: Borobudur Temple in West Java, Mandalika in Lombok Island, Labuan Bajo in Flores Island East Nusa
Tenggara, Bromo-Tengger-Semeru in East Java, the Thousand Islands in North Jakarta, Toba Lake in North Sumatra, Wakatobi in Southeast Sulawesi, Tanjung Lesung in West Java, Morotai in North of Halmahera in maluku Islands and Tanjung Kelayang in Belitung Sumatra. This initiation is a summer breeze for some reasons knowing that Indonesia is opening so many alternative channels for economic development toward tourism. However, the destination is still facing a-never-ending issue; environmental and land use problem. Bali has been occupied by exceeding numbers of hotels and resorts and has been creating the ecological and environmental imbalances. The reclamation plan of Benoa Bay in Bali, for instance, may have a chance to kill abundance coral, ocean habitat, the biggest mangrove forest, and eventually the jobs of fisherman and local businesses.

The study is intended to examine and elaborate strategic answers toward the impacts on the enforcement of Indonesia' tourism establishment particularly the aftermath likelihoods from the initiation of "Ten New Bali", starting with the current standing of Indonesia's tourism, issue of locals' economic growth and leakages within their participation in tourism development, and environmental quality's degradation. The proposed policies decision in conjunction with the initiative works of Indonesian government are expected to be delivered as guidelines for its further tourism implementation. In this study, research questions are: How does the establishment of mainstream tourism destinations in Indonesia create economic vulnerability? How does the establishment of mainstream tourism destinations in Indonesia create likelihood of extensive leakages within local economy? How does the establishment of mainstream tourism destinations in Indonesia create environmental impacts and what are the best policy practices to enforce?

\section{Literature Review}

\subsection{Current Standing of the Competitiveness on Indonesia's Tourism Industry}

Knowing that the measurement of competitiveness is an interesting subject to observe owing to its fact in gearing the successful indicators for tourism industry, competitiveness has always been a complex concept to measure (Kozak \& Remmington, 1998; Go \& Gowers, 2000; Mihalic, 2000; Dwyer, Forsyth, \& Rao, 1999; Mazanec, Wöber, \& Zins, 2017). The study from Sinclair (1999) and Dubarry and Sinclair (2003) illustrated the model of impactful factors on the tourism development that involves political instability, social dispute, terrorism, movement limitation, exchange rate limitation and change in free duty terms, economy 
recession, international fairs, sport events, oil crisis and national day celebration on tourism demand. Another study of identifying the core tourism competitiveness is done by Kozak and Remington (1998) and Haahti and Yavas (1983) by implementing the surveys questioning tourist perception and opinion toward a destination. The surveys results were clear yet still very subjective to the limited indicators of beach areas quality, society friendly and shopping facilities. While the study done by Inskeep (1991) and Middelton (2002) stated that the quality of environment became the major indicator for measuring tourism competitiveness. In addition to that study, World Economic Forum (2013) introduced eight indicators for assessing the identification of tourism competitiveness. The proposed indicators are: human tourism indicator, price competitiveness indicator, infrastructure development indicator, environment indicator, technology advancement indicator, human resources indicator, openness indicator and social development indicator.

The improvement may dominantly caused by the sky rocket numbers of visitors, investment in infrastructure and decentralization implementation on tourism destinations. Effendi (2009) added that the core competencies and competitive advantages of Indonesia's tourism are predominantly involved price competitiveness, rich natural resources, and heritage sites. In addition, Effendi (2009) also delivered their thoughts as why Indonesia is running late over its tourism competitiveness which initially affected by sociopolitical indicators such as the control of deployed act of corruption, law enforcement, effective governance and the value of overall regulation as well as minimum locals' engagements.

\subsection{Tourism Contribution on Economic Growth in Indonesia}

Prior to the theoretical analysis on how the Indonesia's tourism contributes to economic growth, the explanations toward the growth concept and how it is empowered are described in the following citations; in regards of tourism development in Indonesia, related concept of economic growth are mentioned by Christou and Eaton (2000), Papatheodorou (2003) and Sigala and Christou (2003) saying that the need of training and education in tourism are becoming essential factors for both industry-related economic growth and its sustainability. Research and development has likewise been proposed as other determinants of economic growth creating simultaneous increases of potential imported goods and services (Grossman \& Helpman, 1990a, 1990b, 1991; Romer, 1990; Aghion \& Howitt, 1992; Jones, 1999). Growth can also be supplemented by fair provision of public infrastructure aimed to ease the local residents and tourists. Likewise, the intangible growth factor is understood as forms of health care, education and social security from which the interest of social communities within the touristic areas are fairly counted into account (Barro, 1990; Barro \& Sala-i-Martin, 1992, 2004; Baier \& Glomm, 2001; Chen, 2006).

Thanks to the progressive efforts, the set of factor and policy Indonesia government has was able to leverage the travel and tourism sector from rank $70^{\text {th }}$ back in 2013 to stand on rank $50^{\text {th }}$ as of 2015 , according to World Economic Forum (2016)'s Travel and Tourism Competitiveness Report. According to a report by the Indonesia-Investments (2016), Indonesia has targeted up to 12 million international visitors benefiting forecasted exchange earning at IDR172 trillion for 2016. In addition, Indonesia is currently executing several tourism establishment projects in response to the demand of expected domestic trips that reach up to 260 million with total spending of IDR223.6 trillion. The improvement may dominantly caused by the sky rocket numbers of visitors, investment in infrastructure and decentralization implementation on tourism destinations.

According to Indonesia-Investments (2016), the tourism industry in Indonesia has created a great shift of number toward an unemployment rate that stood at 5.81 percent as of February 2015. It is estimated that nearly nine percent of Indonesia's national workforce are working in the tourism industry. According to a report by the Oxford Business Group (2016), the current tourism's growth is expected to enable an engine for the Indonesia's long-term target of 2019 which expects the tourism to contribute up to $8 \%$ to the national economy enabling foreign exchange earnings at IDR240 trillion. At this rate, the expected international arrivals should peak the numbers to 20 million foreign visitors with up to 275 million of domestic visitors.

\subsection{Effects on Tourism's Establishment in Indonesia toward the Environment}

As the competition gets rough, the business perspective in tourism development is somehow, forgets some fundamental principles of environment stability. The creation of "mass tourism" is an initiation Indonesia hardly able to control. Tourists come for better prices and the fact that one of the factors from Indonesia' tourism competitiveness is competitive price. According to Davenport and Davenport (2006), physical development in support of tourism such as resorts, fuel consumption for building and energy, aircraft, trains, buses, overuse of water supply, pollution by vehicle emissions, waste and sewage all responsible to the degradation of the environment. The creation of "mass 
tourism" is a fatal cause for environmental problem from coastal areas, forests and unspoiled lands (Davenport \& Davenport, 2006).

On case citied from an ecotourism study in North Sulawesi, Indonesia, Ross and Wall (1999) mentioned that one of the rich assets Indonesia is blessed from its forests from which the economy contribution can be leveraged dynamically from the preservation of ecotourism. On the contrary, Whitmore (1990) mentioned that with growing number of population demanding natural assets for their food, energy, timber and forest products both for agriculture production of urban development like tourism, has created a massive environmental damages. A report by the World Economic Forum (2016) illustrated the actual misleading policy action Indonesia that is continuously missed; the tourism policy emphasis on environmental sustainability earning dramatic decreases in quality of water used, wildlife preservation, and inevitable deforestation.

A report by the Timber Mafia (2016) mentioned that deforestation caused mostly by illegal logging and burning that reached up to $80 \%$ in percentage making Indonesia the world's third largest emitter of greenhouse gases. Deforestation in Indonesia mostly triggered by the increases of wood-processing production and up to year of 2000 , the production of pulp and paper business made up Indonesia as the world's eleventh largest paper producer. Dramatically, the rate of Indonesia's deforestation rise from 19,192 in 2008 to 32,416 in the following year. Table 2 provides descriptive statistics of forest area, inland water and coastal ecosystem by province in Indonesia.

\subsection{Empirical Model and Hypotheses}

Total factor productivity is the portion of output not explained by traditionally measured inputs of labor and capital used in production. As such, its level is determined by how efficiently and intensely the inputs are utilized in production. The equation below (in Cobb-Douglas form) represents total output $(Y)$ as a function of total factor productivity $(A)$, capital input $(K)$, labor input $(L)$, and the two inputs' respective shares of output ( $\alpha$ and $\beta$ are the share of contribution for $K$ and $L$ respectively). An increase in either $A, K$ or $L$ will lead to an increase in output.

$$
Y=A \times K^{\alpha} \times L^{\beta}
$$

This study aims to demonstrate the impact of mass tourism on economic growth and the environment in the Indonesian economy, thereby enabling useful policy decisions. Accordingly, the following hypotheses are considered:

Hypothesis 1: There is a long-run equilibrium relationship between tourism, economic growth and the environment.

Hypothesis 2: Tourism receipts are related to economic growth in the short-run.

Hypothesis 3: Agriculture land use is related to economic growth in the short-run.

Hypothesis 4: Arable land is related to tourism growth in the short-run.

Hypothesis 5: Forest rent is related to tourism growth in the short-run.

Hypothesis 6: $\mathrm{CO}_{2}$ from transport is related to tourism growth in the short-run.

Table 2. Forest Area, Inland Water, and Coastal Ecosystem in Ten New Bali Destinations.

\begin{tabular}{|c|c|c|c|c|c|c|c|c|}
\hline Province & $\begin{array}{l}\text { Total land of } \\
\text { forest area }^{1)}\end{array}$ & $\begin{array}{c}\text { Deforest } \\
\text { area }^{1)}\end{array}$ & $\begin{array}{l}\text { Deforest } \\
\text { ratio }\end{array}$ & $\begin{array}{c}\text { Water } \\
\text { pollution }\end{array}$ & $\begin{array}{l}\text { Land } \\
\text { pollution }\end{array}$ & \begin{tabular}{|c|} 
Restaurant \\
/Food stall/ $^{3}$ \\
\end{tabular} & Hotel $^{3)}$ & $\begin{array}{c}2016 / 2015 \\
\text { GDP growth }^{4}\end{array}$ \\
\hline CENTRAL JAVA & 757 & 546 & 72.1 & 932 & 183 & 856 & 445 & 105.4 \\
\hline LOMBOK & 1047 & 438 & 41.8 & 122 & 27 & 144 & 81 & 121.2 \\
\hline FLORES & 1809 & 728 & 40.2 & 53 & 14 & 81 & 95 & 105.0 \\
\hline EAST JAVA & 1361 & 782 & 57.5 & 759 & 104 & 877 & 380 & 105.4 \\
\hline WEST JAVA & 817 & 394 & 48.2 & 1131 & 118 & 1189 & 373 & 105.0 \\
\hline NORTH SUMATRA & 3742 & 1968 & 52.6 & 449 & 65 & 511 & 200 & 105.1 \\
\hline SOUTHEAST SULAWESI & 3831 & 963 & 25.1 & 73 & 29 & 72 & 90 & 106.8 \\
\hline BANTEN & 253 & 77 & 30.4 & 251 & 43 & 219 & 85 & 105.3 \\
\hline MALUKU & 3924 & 2864 & 73 & 57 & 13 & 48 & 29 & 105.4 \\
\hline BANGKA BELITUNG & 655 & 434 & 66.3 & 152 & 55 & 74 & 41 & 104.1 \\
\hline BALI & 131 & 9 & 6.9 & 82 & 5 & 173 & 152 & 106.0 \\
\hline INDONESIA TOTAL & 124023 & 66707 & 53.8 & 8786 & 1301 & 7505 & 3464 & 104.9 \\
\hline
\end{tabular}

${ }^{1)}$ Thousand Hectares.

${ }^{2)}$ Number of villages. Villages in this table include the nagari, transmigration settlement unit, and entity of transmigration settlement that is still fostered by the relevant ministries.

3) Number of facilities.

4) GDP growth rate of year 2016 over 2015. According to expenditure GRDP ADH constant $(2010=100)$

Source: The authors have compiled facts and figures from various reports from Indonesian government agencies, including the Ministry of Forestry of Indonesia. 


\section{Research Methodology}

\subsection{Data and Indicators}

The sample is restricted to the period of time in which annual data is available and comparable among variables from 1980 to 2015 (36 observations). All of the time series data below was collected and retrieved from the World Development Indicator (WDI) database published by the World Bank.

Exports of goods and services (current US\$): Exports of goods and services are used as the proxy of total output. Exports of goods and services represent the value of all goods and other market services provided to the rest of the world. They include the value of merchandise, freight, insurance, transport, travel, royalties, license fees, and other services, such as communication, construction, financial, information, business, personal, and government services. They exclude compensation of employees and investment income (formerly called factor services) and transfer payments. Data are in current U.S. dollars.

International tourism, receipts (\% of total exports): International tourism receipts are expenditures by international inbound visitors, including payments to national carriers for international transport. These receipts include any other prepayment made for goods or services received in the destination country. They also may include receipts from same-day visitors, except when these are important enough to justify separate classification. For some countries they do not include receipts for passenger transport items. Their share in exports is calculated as a ratio to exports of goods and services, which comprise all transactions between residents of a country and the rest of the world involving a change of ownership from residents to nonresidents of general merchandise, goods sent for processing and repairs, nonmonetary gold, and services.

International tourism, number of arrivals; International inbound tourists (overnight visitors) are the number of tourists who travel to a country other than that in which they have their usual residence, but outside their usual environment, for a period not exceeding 12 months and whose main purpose in visiting is other than an activity remunerated from within the country visited. When data on number of tourists are not available, the number of visitors, which includes tourists, same-day visitors, cruise passengers, and crew members, is shown instead. Sources and collection methods for arrivals differ across countries. In some cases data are from border statistics (police, immigration, and the like) and supplemented by border surveys. In other cases data are from tourism accommodation establishments. For some countries number of arrivals is limited to arrivals by air and for others to arrivals staying in hotels. Some countries include arrivals of nationals residing abroad while others do not. Caution should thus be used in comparing arrivals across countries. The data on inbound tourists refer to the number of arrivals, not to the number of people traveling. Thus a person who makes several trips to a country during a given period is counted each time as a new arrival.

Travel services (\% of commercial service exports): Travel services (\% of commercial service exports) covers goods and services acquired from an economy by travelers in that economy for their own use during visits of less than one year for business or personal purposes. Travel services include the goods and services consumed by travelers, such as lodging and meals and transport (within the economy visited).

Agricultural land (\% of land area): Agricultural land refers to the share of land area that is arable, under permanent crops, and under permanent pastures. Arable land includes land defined by the FAO as land under temporary crops (double-cropped areas are counted once), temporary meadows for mowing or for pasture, land under market or kitchen gardens, and land temporarily fallow. Land abandoned as a result of shifting cultivation is excluded. Land under permanent crops is land cultivated with crops that occupy the land for long periods and need not be replanted after each harvest, such as cocoa, coffee, and rubber. This category includes land under flowering shrubs, fruit trees, nut trees, and vines, but excludes land under trees grown for wood or timber. Permanent pasture is land used for five or more years for forage, including natural and cultivated crops.

Arable land (\% of land area): Arable land includes land defined by the FAO as land under temporary crops (doublecropped areas are counted once), temporary meadows for mowing or for pasture, land under market or kitchen gardens, and land temporarily fallow. Land abandoned as a result of shifting cultivation is excluded.

Forest rents (\% of GDP): Forest rents are round wood harvest times the product of average prices and a regionspecific rental rate. Forest area (\% of land area) is land under natural or planted stands of trees of at least 5 meters in situ, whether productive or not, and excludes tree stands in agricultural production systems (for example, in fruit plantations and agroforestry systems) and trees in urban parks and gardens.

$\mathrm{CO}_{2}$ emissions from transport (\% of total fuel combustion): $\mathrm{CO}_{2}$ emissions from transport contain emissions from the combustion of fuel for all transport activity, regardless of the sector, except for international marine bunkers and international aviation. This includes domestic aviation, domestic navigation, road, rail and 
pipeline transport, and corresponds to IPCC Source/Sink Category 1 A 3.

\subsection{Descriptive Statistics of Data}

All these time series data have been collected and retrieved from the World Development Indicator database published by the World Bank. For all these time series data are reported on an annual basis and employed for the period from 1980 to 2015 (36 observations). Table 3 displays descriptive statistics along with various summary statistics for the time series. Table 4 displays the results of Pearson correlation analysis between the time series.

\subsection{Unit Root Test}

It is well known in the literature that the data generating process for many economic variables are characterized by stochastic trends that might result in spurious inference if the time series properties are not carefully investigated. A time series is said to be stationary if the mean and autocovariances of the series do not depend on time. Any series that is not stationary is said to be non-stationary (i.e. it has a unit root). The formal method to test the stationarity of a series is the unit root test. There are several well-known tests for this purpose based on individual time series: the augmented Dickey-Fuller (ADF) unit root test (Dickey \& Fuller, 1979, 1981), the Phillips-Perron (PP) unit root test (Phillips \& Perron, 1988), and the Kwiatkowski, Phillips, Schmidt and Shin (KPSS) unit root test (Kwiatkowski, Phillips, Schmidt, \& Shin, 1992), among others.

Table 5 reports the results of unit root tests. All test equations were tested by the method of least squares, including an intercept but no time trend in the model. Probabilities for all tests assume asymptotic normality. In the ADF and PP tests, an optimal lag in the tests is automatically selected based on Schwarz Info Criterion and the lag length (bandwidth) in the tests is automatically selected based on the Newey-West estimator (Newey \& West, 1994) using the Bartlett kernel function. In ADF and PP tests, probability values for rejection of the null hypothesis of a unit root are employed at the 0.05 level based on MacKinnon (1996) one-sided p-values. KPSS tests the null hypothesis: the series has no unit root (the series is stationary), while the alternative hypothesis assumes that the series has a unit root (non-stationary). In KPSS test, probability values for rejection of the null hypothesis are based on Kwiatkowski, Phillips, Schmidt, and Shin (1992) LM statistic p-values.

Table 3. Descriptive Statistics of Indonesia Tourism, Environment and Growth (1995-2015)

\begin{tabular}{|c|c|c|c|c|c|}
\hline & Unit & Minimum & Maximum & Mean & Std. Deviation \\
\hline Tourism Receipts & Million USD & 6.558 & 14.974 & 9.534 & 2.412 \\
\hline Visitor Arrivals & Person & $4,467,021$ & $9,435,411$ & $5,918,897$ & $1,426,328$ \\
\hline Hotels & Number & 1014 & 10435 & 5562 & 4545 \\
\hline Agricultural Land & $\%$ & 23.72 & 31.46 & 28.18 & 2.82 \\
\hline Arable Land & $\%$ & 9.57 & 13.61 & 11.93 & 1.22 \\
\hline Forest Rents & $\%$ & .42 & 1.98 & .76 & .35 \\
\hline $\mathrm{CO}_{2}$ from Transport & $\%$ & 20.70 & 31.85 & 25.81 & 3.54 \\
\hline $\mathrm{CO}_{2}$ Total & Metric Tons & 210,210 & 599,539 & 366,380 & 112,329 \\
\hline GDP Growth Rates & $\%$ & -13.12 & 8.39 & 4.44 & 4.29 \\
\hline
\end{tabular}

Table 4. Pearson Correlations

\begin{tabular}{|c|c|c|c|c|c|c|c|}
\hline & $\begin{array}{c}\text { Tourism } \\
\text { Receipts }\end{array}$ & Visitor Arrivals & Hotels & Forest Rents & Arable Land & $\begin{array}{c}\text { Agriculture } \\
\text { Land }\end{array}$ & $\begin{array}{c}\text { CO2 } \\
\text { Transport }\end{array}$ \\
\hline Visitor Arrivals & .020 & & & & & & \\
\hline Hotels & $.554^{* *}$ & $-.582^{* *}$ & & & & & \\
\hline Forest Rents & $.573^{* *}$ & $-.502^{* *}$ & $.667^{* *}$ & & & & \\
\hline Arable Land & $-.440^{* * *}$ & $.524^{*}$ & $-.692^{* *}$ & $-.761^{* *}$ & & & \\
\hline Agriculture Land & $-.448^{* *}$ & $.691^{* *}$ & $-.816^{* *}$ & $-.796^{* *}$ & $.953^{* *}$ & & \\
\hline $\mathrm{CO}_{2}$ from Transport & .145 & $.903^{* *}$ & -.337 & -.406 & .381 & $.521^{*}$ & \\
\hline GDP & -.203 & $.579^{* *}$ & -.254 & $-.535^{*}$ & .376 & $.439^{*}$ & $.552^{* *}$ \\
\hline
\end{tabular}

Correlation is significant ${ }^{*}$, at the 0.05 level and ${ }^{* *}$, at the 0.01 level (2-tailed). 
Table 5. Results of Unit Root Tests

\begin{tabular}{|c|c|c|c|c|c|c|}
\hline Tests & ADF(0) & ADF(1) & PP(0) & PP(1) & KPSS(0) & KPSS(1) \\
\hline Exports (Service) & -1.258 & $-6.637^{* *}$ & -1.258 & $-6.637^{* *}$ & $0.683^{*}$ & 0.127 \\
\hline Tourism Receipts & -1.247 & $-5.070^{* *}$ & -1.333 & $-5.072^{* *}$ & $0.485^{*}$ & 0.260 \\
\hline Agriculture Land & -0.252 & $-4.918^{* *}$ & -0.307 & $-4.854^{* *}$ & $0.675^{*}$ & 0.077 \\
\hline Arable Land & -0.945 & $-5.136^{* *}$ & -1.138 & $-4.248^{* *}$ & $0.531^{*}$ & 0.077 \\
\hline Forest Rents & -1.944 & $-6.944^{* *}$ & -1.927 & $-9.977^{* *}$ & $0.777^{* *}$ & 0.143 \\
\hline $\mathrm{CO}_{2}$ from Transport & -0.615 & $-5.128^{* *}$ & -0.920 & $-5.127^{* *}$ & $0.589^{*}$ & 0.183 \\
\hline
\end{tabular}

The numeric values in cells are t-statistic.

Probability values for rejection of the null hypothesis are employed at the $5 \%$ significant level ( ${ }^{*}, p$-value $<0.05$ and ${ }^{* *}, p$-value $\left.<0.01\right)$.

\section{Empirical Results}

\subsection{Cointegration Test}

Engle and Granger (1987) point out that a linear combination of two or more non-stationary series may be stationary. If such a stationary linear combination exists, the non-stationary time series are said to be cointegrated. If these variables are cointegrated, then there exists long-run equilibrium among the variables. In other words, if the variables are cointegrated, there is a long-run relationship, and there exists a force to converge into long-run equilibrium. There are two test methods to identify whether there is a long-run relationship among variables: the EngleGranger single equation test method (Engle \& Granger, 1987 ) and the Johansen conintegration test (Johansen, 1988).

Cheung and Lai (1993) report that the Johansen approach is more efficient than the Engle-Granger single equation test method because the maximum likelihood procedure has useful large and finite sample properties. The Johansen cointegration test models each variable as a function of all the lagged endogenous variables in the system. The Johansen procedure uses two ratio tests: a trace test and a maximum eigenvalue test, to test the number of cointegration relationships. Both tests can be used to determine the number of cointegrating vectors present, although they do not always indicate the same number of cointegrating vectors. If trace statistics and maximum eigenvalue statistics yield different results, the result of the maximum eigenvalue test is preferred due to the benefit of carrying out separate tests on each eigenvalue.

Table 6 reports the results of the Johansen cointegration test. The test equation was tested by the method of least squares. The regression model allows for a linear deterministic trend in data and includes intercept but no trend in vector autoregressive models. For the two likelihood ratio test statistics, the probability value for rejection of the null hypothesis of no cointegration is based on the MacKinnon, Haug, and Michelis (1999) p-values. The null hypothesis of no cointegration is rejected at the $5 \%$ significance level. The trace test indicates at least two cointegrating equations exist at the 0.05 level, while the maximum eigenvalue test indicates at least one cointegrating equation exists at the 0.05 level. Therefore, the null hypothesis of no cointegration can be rejected at the 0.05 level. Considering the results of the Johansen cointegration test in Table 6 , this study concludes that hypothesis 1 that there is a long-run equilibrium relationship between tourism receipts, environmental degradation and economic growth in Indonesia, is supported.

Table 6. Results of Johansen Cointegration Test

\begin{tabular}{|c|c|c|}
\hline $\begin{array}{c}\text { Number of } \\
\text { cointegration }(\boldsymbol{r})\end{array}$ & Trace statistic & $\begin{array}{c}\text { Maximum } \\
\text { eigenvalue statistic }\end{array}$ \\
\hline$r=0$ & $123.363^{\star *}$ & $43.301^{\star *}$ \\
\hline$r \leq 1$ & $76.062^{*}$ & 31.785 \\
\hline$r \leq 2$ & 44.276 & 23.586 \\
\hline$r \leq 3$ & 20.690 & 13.495 \\
\hline$r \leq 4$ & 7.195 & 5.334 \\
\hline$r \leq 5$ & 1.860 & 1.860 \\
\hline
\end{tabular}

Regression model: Exports (Service) $=$ Tourism receipts + Agriculture land + Arable land + Forest rents $+\mathrm{CO}_{2}$ from transport The numeric values in cells are trace statistic and maximum eigenvalue statistic.

Cointegrating equations are significant at the 0.05 level $\left({ }^{*}, p\right.$-value < 0.05 and $^{* *}$, p-value $<0.01$ ).

\subsection{Cointegrating Regression Analysis}

Considering the results of the Johansen cointegration test in Table 6, it is evident that there is a long-run equilibrium relationship between TFP growth factors and total output in Pakistan. In this case, an unrestricted vector autoregressive model would not be an effective option for testing short-run dynamics. Engle and Granger (1987) noted that if two or more time series variables are cointegrated, there is always a corresponding error correction representation in which the short-run dynamics of the variables in the system are 
influenced by the deviation from equilibrium. The cointegrated variables must have an error correction representation in which an error correction term is incorporated into the model. In this case, a vector error correction model is formulated to reintroduce the information lost in the differencing process, thereby allowing for long-run equilibrium as well as short-run dynamics. The vector error correction model implies that changes in one variable are a function of the level of disequilibrium in the cointegrating relationship (i.e. captured by the error correction term), as well as changes in other explanatory variables. There are several estimation methods for testing a single cointegrating vector, an error correction term. These are fully modified OLS (Phillips \& Hansen, 1990), canonical cointegrating regression (Park, 1992), and dynamic OLS (Saikkonen, 1992; Stock \& Watson, 1993).

Phillips and Hansen (1990) propose an estimator that employs a semi-parametric correction to eliminate the problems caused by the long-run correlation between the cointegrating equation and stochastic regressor innovations. The Fully Modified OLS (FMOLS) estimator is asymptotically unbiased and has fully efficient mixture normal asymptotes allowing for standard Wald tests using asymptotic Chi-square statistical inference (Hansen, 1992). The FMOLS estimator employs preliminary estimates of the symmetric and one sided long-run covariance matrices of the residuals. The canonical cointegrating regression (Park, 1992) is closely related to FMOLS, but instead employs stationary transformations of the data to obtain least squares estimates to remove the long-run dependence between the cointegrating equation and stochastic regressor innovations. Like FMOLS, the canonical cointegrating regression (CCR) estimates follow a mixture normal distribution, which is free of non-scalar nuisance parameters and permits asymptotic Chi-square testing. The CCR transformations asymptotically eliminate the endogeneity caused by the long-run correlation of the cointegrating equation errors and the stochastic regressor innovations, and simultaneously correct for asymptotic bias resulting from the contemporaneous correlation between the regression and stochastic regressor errors (Park, 1992). Estimates based on CCR are therefore fully efficient and have the same unbiased, mixture normal asymptotics as FMOLS (Park, 1992).

Saikkonen (1992) and Stock and Watson (1993) propose a simple approach to constructing an asymptotically efficient estimator that eliminates the feedback in the cointegrating system. The Dynamic OLS (DOLS) method involves augmenting the cointegrating regression with lags and leads of $\Delta X_{t}$ so that the resulting cointegrating equation error term is orthogonal to the entire history of the stochastic regressor innovations. The model employs an intercepttrend specification for the cointegrating equation, with no additional deterministic in the regressor equations, and four lags and leads of the differenced cointegrating regressor to eliminate long-run correlation between the innovations. Under the assumption that adding lags and leads of the differenced regressors soaks up all of the long-run correlation between long-run variances, least-squares estimates of the equation have the same asymptotic distribution as those obtained from FMOLS and CCR (Saikkonen, 1992; Stock \& Watson, 1993).

Table 7. Results of Cointegrating Regression Analysis

\begin{tabular}{|c|c|c|c|}
\hline Estimation Method & FMOLS & CCR & DOLS \\
\hline Tourism Receipts & $0.007(0.002)^{*}$ & $0.007(0.003)^{*}$ & $0.001(0.003)$ \\
\hline Agriculture Land & $0.558(0.145)^{\star *}$ & $0.563(0.045)^{* *}$ & $0.600(0.030)^{* *}$ \\
\hline Arable Land & $-0.786(0.122)^{\star *}$ & $-0.792(0.120)^{\star *}$ & $-0.993(0.089)^{* *}$ \\
\hline Forest Rents & $-0.273(0.242)$ & $-0.244(0.201)$ & $-0.084(0.199)$ \\
\hline $\mathrm{CO}_{2}$ from Transport & $-0.009(0.020)$ & $-0.009(0.020)$ & $-0.0002(0.012)$ \\
\hline Cointegrating equation deterministics & $16.657(1.106)$ & $16.552(1.144)$ & $17.993(0.685)^{\star \star}$ \\
\hline R-squared & 0.933 & 0.933 & 0.994 \\
\hline Adjusted R-squared & 0.922 & 0.922 & 0.985 \\
\hline Long-run Variance & 0.094 & 0.094 & 0.010 \\
\hline Cointegration Coefficient Diagnostic ${ }^{1}$ & $\begin{array}{c}16.657(1.106)^{* *} \\
D F=29\end{array}$ & $16.552(1.144)^{\star *}$ & $17.993(0.685)^{\star *}$ \\
\hline Cointegration Test $^{2}$ & $0.636(0.189)$ & $0.396(0.200)$ & $0.116(0.200)$ \\
\hline
\end{tabular}

Regression model: Exports (Service) $=$ Tourism receipts + Agriculture land + Arable land $(+/-)+$ Forest rents $(+/-)+\mathrm{CO}_{2}$ from transport(+/-) Probability values for rejection of the null hypothesis are employed at the $5 \%$ significant level $\left({ }^{*}, p\right.$-value $<0.05$ and ${ }^{* *}, p$-value $\left.<0.01\right)$. The numeric values in cells are coefficients of regressors and standard errors follow in parenthesis.

${ }^{1}$ Cointegration coefficient diagnostic test has been conducted by Wald test.

${ }^{2}$ Cointegration test has been conducted by Hansen parameter instability test for the null hypothesis (null hypothesis: series are cointegrated). 
Table 7 reports the results of cointegrating regression analysis using FMOLS, CCR and DOLS. In testing hypothesis 2 and 3 that tourism growth and agriculture land growth lead to the increase of total output the short-run, Table

7 shows that tourism growth (i.e. tourism receipts) is significant at the 0.05 level and agriculture growth (i.e. agriculture land) is also significant at the 0.01 level. The results confirm that tourism growth and agriculture land growth are positively related to the increase of total output in Indonesia.

In testing hypothesis 4,5 and 6 that arable land, forest rents and $\mathrm{CO}_{2}$ emissions from transport are related to the increase of tourism and total output in the short-run, Table 7 shows that arable land is significant at the 0.01 level in Indonesia, but forest rents and $\mathrm{CO}_{2}$ from transport are not significant in Indonesia. The results confirm that arable land is negatively related to the increase of total output in Indonesia. That is, when tourism growth in the economy is getting realized it shows that the environmental degradation increases greatly in inverse in the model, eventually negative impacts to the environment.

\section{Discussion and Policy Implication}

Having demolished their own particular condition, having either spent or annihilated all that is regular, individuals from the propelled shopper social orders are constrained to search for normal natural life, rich greenery and brilliant shorelines somewhere else. At the end of the day, they search for different situations to expend. In this manner equipped with their packs, voyagers continue to expend nature in the nations of the Third World - that last 'untainted' comer of earth. In a significant number of the Third World nations today, the conviction that tourism can get the genuinely necessary foreign exchange to support their hanging economies has gotten on with extraordinary speed and positive thinking. In any case, it is being understood that foreign exchange profit from tourism are not as incredible as they appear to be, while the natural and social reactions are averse to the point that Third World inhabitants may ponder whether the visitor exchange is justified, despite all the trouble all things considered.

Middleton and Clarke (2001) list a number of economic advantages and disadvantages of these micro-businesses:

- The money earned by micro-businesses tends to stay in the local community - they typically purchase locally and are part of the fabric of the local money circulation cycle.

- They are a vital element in job creation in rural areas and less developed regions in general.
- They do not have the commercial rationale that dominates big enterprises.

Typically, 'Numbered in their hundreds of thousands, micro-businesses are unique as individual enterprises and they cannot be standardized - to attempt to do so would destroy their contribution. Unfortunately, this makes them amorphous and difficult to measure and "badge" as a coherent sector.'

In such ways, both tourism fixation and expansion have potential focal points for business gainfulness, goal intensity and supportable advancement. Significantly, the two methodologies likewise have potential disservices for business suitability and for manageability, and those hindrances can be extremely generous. It is fundamental for approach producers, organizers, organizations and natives to know about such potential favorable circumstances and weaknesses, and to think of them as precisely in the particular setting and conditions of every goal. Before such appraisals can be made, be that as it may, a sound gratefulness is expected of the components, procedures and linkages associated with essential tourism item advancement in goals. To help with these appraisals, the paper recognizes and assesses a few of the most critical components, procedures and linkages. The paper makes another commitment by giving a fuller comprehension of these urgent issues for goals, including by creating reasonable systems to help understanding.

\section{Conclusions}

The paper has contended that there is a requirement for more research with a predictable spotlight on understanding the highlights and connections related with essential tourism items in goals. An expansive, social point of view on goal item get together can help with this examination as it guides consideration regarding the connections required with tourism items and item improvement forms, incorporating with their more extensive settings. Essential tourism items are scratch draw cards that incite voyagers to visit a goal, but then there are shockingly few thoughtfully engaged examinations analyzing their shifted components, the procedures through which they work and are between associated, or how those highlights and procedures are showed in various goals. The idea of tourism item get together in goals can guide thoughtfulness regarding these issues. This paper has started to inspect logically and reasonably the distinctive components, procedures and connections that are included with this gathering.

Future investigations of the assembly of essential tourism items in destinations could investigate in more profundity the product highlights, forms and vital alternatives recognized in 
the paper. These investigations may helpfully apply the wide and social systems introduced here. The particular highlights, blends and procedures will shift as per every goal's unique situation, however appraisals of such unexpected varieties between spots will help in seeing more broad procedures.

\section{References:}

Aghion, P., \& Howitt, P. (1992). A model of growth through creative destruction. Econometrica, 60(2), 323-351.

Bair, S. L., \& Glomm, G. (2001). Long run growth and welfare effects of public policies with distortionary taxation. Journal of Economic Dynamics and Control, 25, 2007-2042.

Barro, R. J. (1990). Government spending in a simple model of endogenous growth. Journal of Political Economy, 98, 103-125.

Barro, R. J., \& Sala-i-Martin, X. (1992). Public finance in model of economic growth: Review of Economic Studies, 54, 646-661.

Barro, R. J., \& Sala-i-Martin, X. (2004). Economic Growth. Cambridge, MA: MIT Press.

Chen, B. L. (2006). Economic growth with an optional public spending composition. Oxford Economics Papers, 58 123-136.

Cheung, Y. W., \& Lai, K. S. (1993). Finite-sample sizes of Johansen's likelihood ratio tests for cointegration. Oxford Bulletin of Economics and Statistics, 55, 313328.

Christou, E., \& Eaton, J. (2000). Management competencies for graduate trainees of hospitality and tourism program. Annals of Tourism Research, 27, 10581061.

Davenport, J., \& Davenport, J. L. (2006). The impact of tourism and personal leisure transport on coastal environments: A review. Estuarine Coastal and Shelf Science, 67(1), 280-292. DOI:10.1016/j.ecss.2005.11.026.

Dickey, D. A., \& Fuller, W. A. (1979). Distribution of the estimators for autoregressive time series with a unit root. Journal of the American Statistical Association, 74, 427-431.

Dickey, D. A., \& Fuller, W. A. (1981). Likelihood ratio statistics for autoregressive time series with a unit root. Econometrica, 49, 1057-1071.

Dubarry, R., \& Sinclair, M. T. (2003). Market share analysis: The case of French tourism demand. Annals of Tourism Research, 30, 927-941.

Dwyer, L., Forsyth, P., \& Rao, R. (1999). A sectoral analysis of price competitiveness of Australian tourism.
Working Paper, Ninth Australian tourist and hospitality research conference, Adelaide, Australia.

Effendi, E. S. (2009). The Impact of Foreign Competitiveness on Industry's Performance: A Study in Tourism Industry in Batam and Bintan, Riau Island, Indonesia. PhD Dissertation in Strategic Management. Faculty of Economy, University of Indonesia.

Engle, R. F., \& Granger, C. W. J. (1987). Cointegration and error correction: Representation, estimation and testi ng. Econometrica, 55, 251-276.

Go, F., \& Govers, R. (2000). Integrated quality management for tourist destinations: A European perspective on achieving competitiveness. Tourism Management, 21(1), 79-88.

Grossman, G. M., \& Helpman, E. (1990a). Comparative advantage and long-run growth. American Economic Review, 80(4), 796-815.

Grossman, G. M., \& Helpman, E. (1990b). Trade, innovation and growth. American Economic Review, 80(2), 8691.

Grossman, G. M., \& Helpman, E. (1991). Innovation and Growth in the Global Economy. Cambridge MA: MIT Press. ISBN: 9780262071369.

Haahti, A. J., \& Yavas, U. (1983). Tourist perspections of Finland and selected European countries as travel destinations. European Journal of Marketing, 17(2), 34-42. https://doi.org/10.1108/EUM0000000004833

Hansen, B. E. (1992). Tests for parameter instability in regressions with $\mathrm{I}(1)$ processes. Journal of Business and Economic Statistics, 10, 321-335.

Indonesia-Investments. (2016). Tourism Industry Indonesia. Retrieved on December 20, 2016, from https://www.indonesia-investments.com/business/ industries-sectors/tourism/item6051

Inskeep, E. (1991) Tourism Planning: An Integrated and Sustainable Development Approach. New York, NY: Van Nostrand Reinhold.

Johansen, S. (1988). Statistical analysis of cointegration vectors. Journal of Economic Dynamics and Control, 12, 231-254.

Jones, C. I. (1999). Growth: With or without scale effects. American Economic Review, 89, 139-144.

Kozak, M., \& Rimmington, M. (1998). Benchmarking: Destination attractiveness and small hospitaly business performance. International Journal of Contemporary Hospitality Management, 10(5), 184188.

Kwiatkowski, D., Phillips, P. C. B., Schmidt, P., \& Shin, Y. (1992). Testing the null hypothesis of stationary against the alternative of a unit root. Journal of Econometrics, 54, 159-178. 
MacKinnon, J. G. (1996). Numerical distribution functions for unit root and cointegration tests. Journal of Applied Econometrics, 11, 601-618.

Mackinnon, J. G., Haug, A. A., \& Michelis, L. (1999). Numerical distribution functions of likelihood ratio tests for cointegration. Journal of Applied Econometrics, 14, 563-577.

Mazanec, J. A., Wöber, K., \& Zins, A. H. (2017). Tourism Destination Competitiveness: From Definition to Explanation? Journal of Travel Research, 46(1), 8695. https://doi.org/10.1177/0047287507302389

Middelton, V. (2002). A national strategy for visitor attractions. An analysis of travel and tourism competitiveness versus socio-political condition at the national level. An Indonesian Case Study, 1, 385400.

Mihalic (2000). Environmental management of a tourist destination: A factors of tourist competitiveness. Tourism Management, 21(1), 65-78.

Middleton, V. T. C., \& Clarke, J. (2001). Marketing in Travel and Tourism (3rd Ed.). Oxford, UK: ButterworthHeinemann Elsevier Ltd.

Newey, W., \& West, K. (1994). Automatic lag selection in covariance matrix estimation. Review of Economic Studies, 61, 631-653.

Oxford Business Group. (2016). Indonesia's Tourism as Main Source of Foreign Exchange. Retrieved on December 20, 2016, from https://www.oxfordbusinessgroup.com/overview/natu ral-attraction-government-taking-multi-prongedapproach-order-bolster-visitor-numbers

Papatheodorou, A. (2003). Exploring the determination of student performance in university modules and streams. Applied Economics, 35, 1869-1864.

Park, J. Y. (1992). Canonical cointegrating regressions. Econometrica, 60, 119-143.

Phillips, P. C. B., \& Hansen, B. (1990). Statistical inference in instrumental variable regression with $\mathrm{I}(1)$ processes. Review of Economic Studies, 57, 99-125.

Phillips, P. C. B., \& Perron, P. (1988). Testing for a unit root in time series regression. Biometrica, 75(2), 335-346.

Romer, P. (1990). Endogenous technological change. The Journal of Political Economy, 98(5), S71-S102.

Ross, S., \& Wall, G. (1999). Ecotourism: Towards congruence between theory and practice. Tourism Management, 20(1), 123-132.
Saikkonen, P. (1992). Estimation and testing of cointegrated systems by an autoregressive approximation. Econometric Theory, 8, 1-27.

Sigala, M., \& Christou, E. (2003). Enhancing and complementing the instruction of tourism and hospitality courses through the use of online educationtTools. Journal of Hospitality and Tourism Education, 15, 6-16.

Sinclair, M. T. (1990). Tourism Development in Kenya. Washington, DC: World Bank.

Stock, J. H., \& Watson, M. (1993). A simple estimator of cointegrating vectors in higher order integrated systems. Econometrica, 61, 783-820.

Timber Mafia. (2016). Indonesia deforestation and illegal logging. Retrieved on December 20, 2016, from http://www.abc.net.au/4corners/content/2002/timber_ mafia/resources/resources_indonesia.htm.

Tunggono, V. (2016). Indonesia will have 10 Bali-like destinations in the next four years. Retrieved on December 20, 2016 from Brilio.net: https://www.brilio.net/en/news/indonesia-will-have-10 -new-bali-like-destinations-in-the-next-4-years-10new-bali-like-destinations-.html

Whitmore, T. (1990). Tropical Rain Forests. Oxford, United Kingdom: Clarendon Press.

World Economic Forum. (2013). The Travel \& Tourism Competitiveness Report 2013: Reducing Barriers to Economic Growth and Job Creation. Geneva, Switzerland: World Economic Forum. Retrieved April 18, 2016, from: http://www3.weforum.org/docs/ WEF_TT_Competitiveness_Report_2013.pdf

World Economic Forum. (2016). The Travel \& Tourism Competitiveness Report 2015: Indonesia's Tourism Policy and Competitiveness. Geneva, Switzerland: World Economic Forum. Retrieved on November 29, 2016, from http://www3.weforum.org/docs/TT15/ WEF_Global_Travel\&Tourism_Report_2015.pdf

World Travel \& Tourism Council. (2017). Travel \& Tourism Economic Impact 2017 Indonesia. London, United Kingdom: World Travel \& Tourism Council. Retrieved April 18, 2018, from: https://www.wttc.org/-/media /files/reports/economic-impact-research/countries2017/indonesia2017.pdf 